\title{
Metaphors in the Quran and its translation accuracy in Indonesian
}

\author{
Yayan Nurbayan \\ Department of Arabic Education, Faculty of Language and Literature Education, Universitas Pendidikan Indonesia, \\ Jl. Dr. Setiabudhi No. 229 Bandung 40154, West Java, Indonesia
}

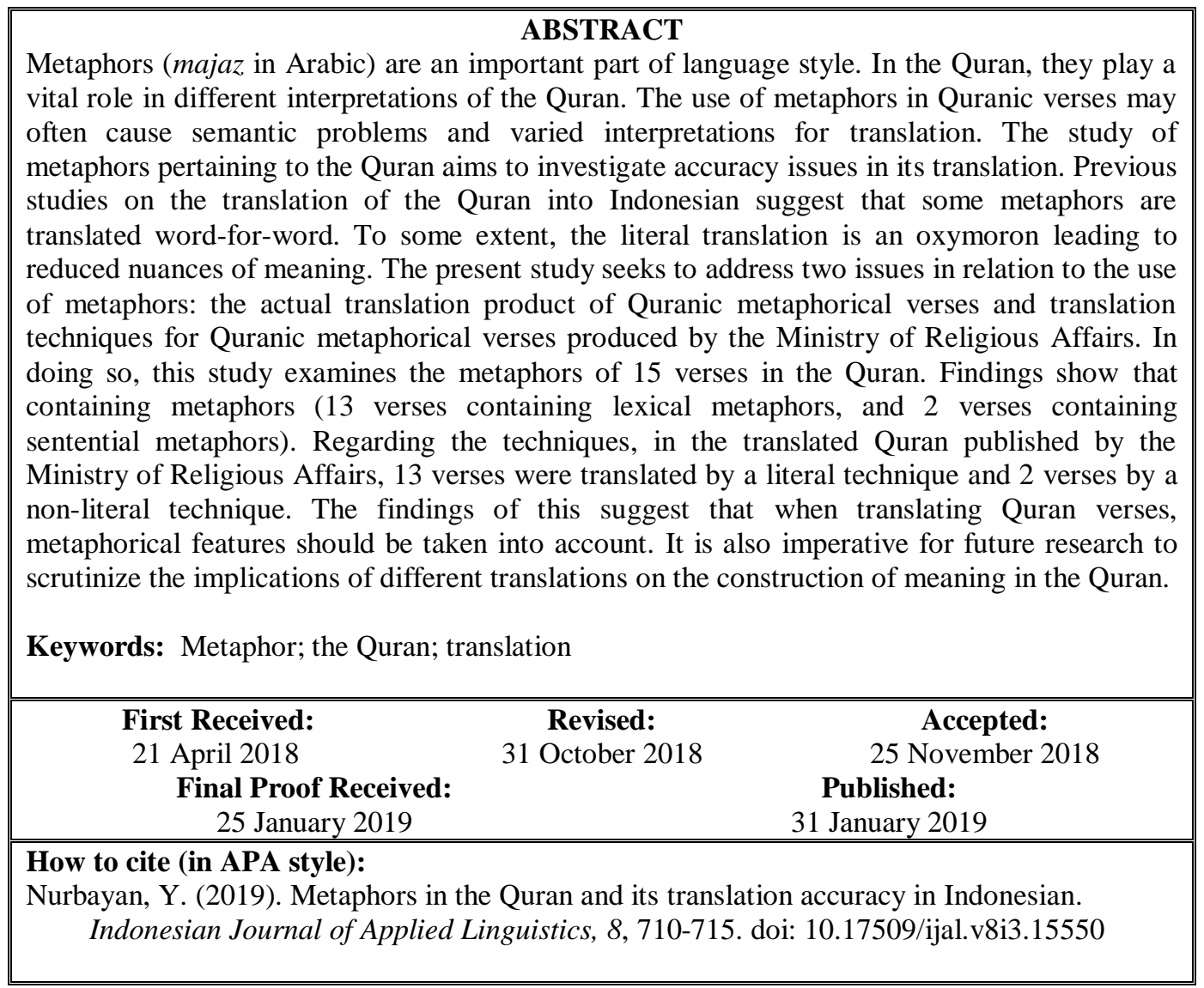

\section{INTRODUCTION}

In today's globalized world, translation studies on metaphors in the Quran have contributed to a nuanced understanding of linguistics and cultural dimensions of a target language (TL) and a source language (SL). The interpretation of metaphors is strongly culturally conditioned. This is especially the case with translated metaphor. Adopting a metaphor to a new context a translator can choose among three possibilities: he or she can use an exact equivalent of the original metaphor $(\mathrm{M} \rightarrow \mathrm{M}$ procedure); he or she can seek another metaphorical phrase which would express a similar sense (M1 $\rightarrow \mathrm{M} 2$ procedure); finally, he or she can replace an untranslatable metaphor of the original with its approximate literal paraphrase (the $\mathrm{M} \rightarrow \mathrm{P}$ procedure) (Dobrzynska, 1995). Eliman (2016) found that 90\% of metaphor translations in the Quran to English failed to convey accurate meanings. The general strategies of translation are inept at affirming the rich nuance of metaphors in the Quran. More specifically, the strategies used do not fall into the types of metaphors. The concept of equivalence is believed to be a central issue in translation although its definition, relevance, and applicability within the field of translation theory have caused heated controversies. Indeed, "Equivalence" has provided a useful theoretical and pragmatic foundation for translation processes (Kashgary, 2011). 


\section{Metaphors in the Quran}

Metaphors are part of Quranic discourse. Interpreting metaphorical verses in the Quran is hotly debated among scholars. Some argue that metaphorical verses are compulsory to be taken connotatively. This is because the Quran follows the development of language at a specific time. In this regard, Zarkasyi (1975) argues that at the time the Quran was revealed, Arabs used to make use of majaz, tasybih, and kinayah styles in their daily utterances. However, Sanqiti (2009) emphasize that metaphors, in linguistics, are connotative; therefore, as the words of God, the Quran, is impossible to have connotative meanings. It is the basis of considering metaphors as denotative in meaning. For that reason, it is necessary to conduct comprehensive studies on metaphors in Quranic verses.

Nurbayan (2009) argues that metaphors in the Quran contribute to polemics among scholars. The selection of a particular metaphorical meaning has profound legal and belief implications. Therefore, Sanqiti (2009) points out that metaphors are related to emptiness and lies by which people use to calumniate. On the contrary, Al-Tabari (2000) contends that metaphors reflect the beauty of language that exists in the Quran. Such metaphors have been used long before the establishment of the Quran. Linguistically, Alexandrien introduced the term in the first century AD (as cited in Syamsuddin, 2009, p. 12). Disagreement about metaphors in the Quran is a critical topic among translators. They need to consider prudence, appropriate methods, and suitable procedures.

In an Islamic tradition, the study of the Quran is divided into two topics; ma haulal Quran (the study of Quranic topics) and dirasat fil Quran nafsihi (the study of the Quran). From this perspective, metaphors can be categorized into the second topic as they are part of language structure in the Quran (Nawawi, 2017, p. 239). Metaphors are used as a language style in Arabic as a result of a long process of language development among Arabs. Historically, humans first used the word based on its original meaning: a connotative meaning. Overtime, humans modify their language practice by using, among others, metaphors and euphemism. In balaghah, metaphors are discussed in bayan with such topics, as tasybih and kinayah. Metaphor is an advanced topic of a language style, such as tasybih (parable). This study was initiated by the Prophet's closest companions to construct a moderate interpretation of metaphorical Quranic verses (Atiq, 1985).

In contemporary Arabic analysis, metaphors are treated as an opposite term of hakikat (Muzakki, 2009). Hakikat is an agreed basic term as an initial meaning in language (Ibn Jinni, 1343; Ibnul Atsir, 1939). A metaphor is a voice (word or sentence) that represents an indirect meaning, as it reflects more than a single meaning (Sukamta, 2009). Jurzani (1988, p. 365), pinpoints that a metaphor is an expression whose meaning goes beyond its original meaning. Hasyimi
(1994), in a different sense, maintains that a metaphor is an expression used in different meaning as the relation and qarinah (signified) are closely intertwined. In this sense, a metaphor is a word used to represent indirect meaning (Lubis, 2011).

\section{Translation of metaphorical verses in the Quran}

Metaphors can be defined as a linguistic sign used in the predicative function outside its normal usage as determined by the code. Metaphorical sense emerges through exploiting the set of associations that accompany linguistic elements in the consciousness of code users. This pragmatic material is a more amorphous complex than ordinary linguistic meaning. The sets of associations fixed in the consciousness of native speakers of a given language make metaphorical communication always extremely 'sensitive' to the communicative context (Dobrzynska, 1995).

Furthermore, the studies on the translation of the Quran in Indonesian are also popular. Ainurrafiq (2015) found that there are typical mistakes in translation from Arabic to Indonesian; such as grammatical accuracy of the translation results are grammatically inaccurate sentential redundancy, inappropriate literal translations, and improper use of identical terms from a source language (assuming that people are already familiar with the terms).

Al Farisi (2010) reported that the translation of the Quran published by the Ministry of Religious Affairs adopted $60 \%$ literal strategy for translating iltifat verses. This was attributed to foreignization in translating the verses (Al Farisi, 2015). In a different study, Al Farisi (2013) revealed that $93.3 \%$ of the readers did not employ complex processing efforts to understand the translated version of kinayah verses with taboo expressions. The results showed the imperfection in translating Quranic verses into Indonesian. It is necessary for the government (Ministry of Religious Affairs) to consider some valuable insights into the quality of the translation product of the Quran.

Culture and language cannot separate from translation. Nowadays, the issue of bilinguality or knowing another language is not the only prerequisite for being a translator; in this fast-moving world, translators should be primarily cultural experts. In other words, they should know the two cultures (source and target) very well before starting to act as a translator. (Mahadi, 2015).

There are five conditions related to the naturalness level, such as (1) avoiding literal translation (Belloc, 1931), (2) making readers realize that it is a translation product (Rahimy, 2004), (3) adding appropriate words to a target language (Tytler, 1797), (4) understanding readers from their target language (Nida, 1943), and (5) using a communicative strategy (Newmark, 1998). In a broader context, reduction or addition can result in unwanted consequences for people who use translation works, such as translation texts in the fields of law, medicine, religion, and engineering (Nababan, Ardiana, $\&$ Sumardiono, 2012; pp. 39-57). A qualified translation 
product has to meet the aspects of accuracy, acceptability, and legibility.

The typical problem in translation is finding equivalent words. Regarding the problem, Nida (1969) explains that there are formal equivalence and dynamic equivalence. Formal equivalence focuses on the messages (form or content), while the dynamic equivalent is related to constructing equivalent nuances by considering the relationship between the substantial message in the source language and the target language. These problems are faced by many translators, as reported by Seong (2011) that it is hard to find the equivalent verb of Chinese and Malay.

In addition, cultural issues are embedded in the translation process. According to Larson (1998), cultural aspects are very important in translation, as translating is not merely about changing words, but also transferring cultural values of the words. For this reason, a translator needs to consider these two aspects. Meaning is a crucial and complex term in language. Therefore, a translator is highly recommended to be meticulous in seeing different languages from different cultures. A translator is to translate words (into target language) that can be accepted by the readers of the target language (Thriveni, 2002). As an example, Shanmugam (2010) shows that the proverbs in the Malay-speaking rhymes exhibit universal meanings; however, the metaphors are unique and distinctive. For this reason, the present study aims to examine the representation of metaphors in the Quran.

\section{THE STUDY}

The primary data in this research were the metaphorical verses and their translations in the Qur'an published by the Ministry of Religious Affairs of the Republic of Indonesia. The verses were treated as texts by emphasizing that they are a revelation of Allah. With this in mind, this is a qualitative study with an analytical discourse. The samples were taken purposively in accordance with the metaphorical aspects in the first chapter. After finding the metaphors, the translations were analyzed by considering the principles of translation.

This study involved primary and secondary data sources. The primary data were metaphorical Quranic verses and their translations in Indonesian; the secondary data were Qur'anic interpretation books providing additional insights and topics about the primary data. The books under the study were Alkasysyaf by Zamakhsyari (2009) and the Almunir fil Aqidah qasysyari'ah wal manhaj by Az-Zuhaili (2009). These books are considered relevant because there are linguistic descriptions of metaphorical verses. The books on balaghah supplemented the metaphor analysis.

This study examined the accuracy of the translation of metaphorical verses. The procedure used in this study included (1) identifying metaphorical verses, (2) explaining the translation products in Indonesian, and (3) analyzing the accuracy, clarity, and naturalness.

\section{FINDINGS AND DISCUSSION}

The findings of this study focus on metaphors and types of translation strategies by the translator of the Ministry of Religious Affairs of the Republic of Indonesia. The representation of metaphors was found in 15 Quranic verses. The types of metaphors were at lexical, phrasal, and causal levels. It was found that there are eight wordmetaphors, ختم (Albaqarah 7), اشترو ا (Albaqarah 16), عهر الت (Albaqarah 27), تشتروا (Albaqarah 41), اركو ا (Albaqarah 43), وجهومه (Albaqarah 49), ورونكم (Albaqarah 112), السُُّجُود (Albaqarah 125). There are two phrasal

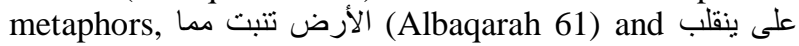
عقبيه (Albaqarah 163). In clausal forms, there are four findings, الأنهار تحتها من تجرِي (Albaqarah 125) and وأثربو (Albaq) (Albaqarah 93).

Regarding the strategy, there are literal and nonliteral strategies used by the translator. The literal strategy is identifiable in translating the words ختحو تنبت مما ,السجود ,وجهه ,يسومونكم ,اركعوا , تشتروا , ينقضون ,اشتروا

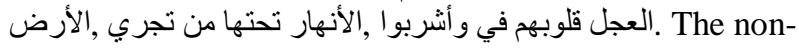
literal strategy was implemented in translating the

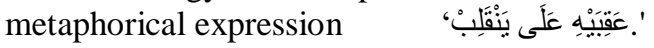

It was found that there are 15 metaphorical Quranic verses. The metaphors could be seen in Albaqarah 7, 16, 25, 27, 41, 43, 49, 61, 74, 93, 112, 115, 125,143 , and 144. Based on the analysis, there are eight word-metaphors in Al-baqarah 7, 16, 27, 41, 43, 49, 112 and 125. In Al-baqarah 7, there is a clausal-metaphor

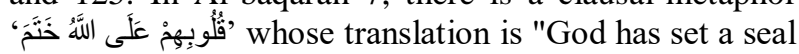
on their hearts." In this clause, there is a word '(based on Ashihhah's dictionary, which means balagha akhiruhu (till the end or finish something) (see Jauhari, 2009 , p. 305). In this specific context, the word was not translated as 'menutup/close,' but 'mengunci/set a seal,' which commonly refers to a close door, box, or enclosed object. In the respective verse, the word is suitable for the subject 'hati/heart.' The construction, in balaghah, is defined as a metaphor. The translation of خَنََّ as 'lock' is a literal strategy. This translation is accurate, understandable, and grammatically correct. It

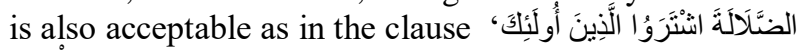
بِالْهُخَى

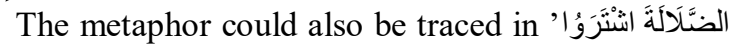
'بِالْهُدَى translated as 'menjualbelikan kesesatan dengan hidayah/perform a transaction between digression and holy guidance.' As Abadi (2005, p. 1229), point out, the word "أثْنَرَوُ " has the basic meaning of 'memiliki sesuatu dengan cara membeli/having something by buying.' In this context, the word is referred to as 'exchanging.' The people are exchanging digression with holy guidance. It implies that God uses the metaphor in transferring his message as he does not use the word

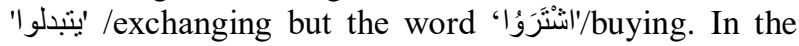
Indonesian translation version, it is translated as 'mereka itulah orang yang membeli kesesatan dengan petunjuk/they are people who bought digression with guidance.' It is indeed a literal translation; the words are translated word for word. However, the metaphorical aspect appears in the source and target language.

In Al-baqarah 27, there is the word ' $a h d u$ ' 
categorized as a metaphor. Asfahani (2009, p. 591), emphasizes that the word means ihtifadh (keep something). The word is originally used for the elders in talking about legacy. The message is called as ahdu because it is sacred for them. The word also has an alternative meaning; it is 'a serious promise.' In this context, ahdu refers to 'rop knot' by deleting musyabah bih to symbolize the typically of 'rope.'

In Al-baqarah 41, there is a metaphor in the

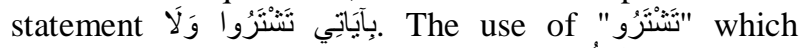

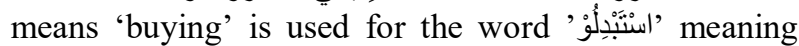
'changing.' In the translation made by the Ministry of

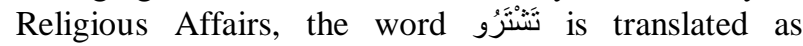
'selling.' The original meaning of the word is 'buying' (Ibn Faris, 1979, p. 266). The translation was inaccurate, and the appropriate word is 'transaction' as it is not only forbidden to sell, but also buy.

In Al-baqarah 43, there are metaphorical words in

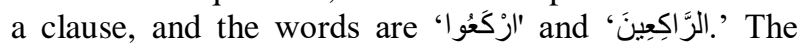
words are categorized as metaphors as the word ' $r u k u$ ' is used to refer to 'prayer.' The word "ارْكَعُو ا" lexically means 'bending your head.' In praying rituals, ruku means bending your head, so it is in parallel with your knees; this is performed after reciting Al-fatihah (Abadi, 2005, p. 723). The strategy used by the Ministry in translating the word is a literal translation. Consequently, the word is inaccurately translated as the core message has vanished.

In Al-baqarah 49, the metaphor could be found in

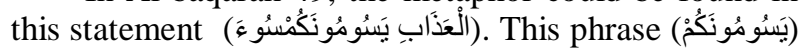

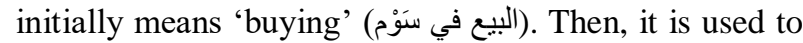
replace the meaning of 'feeling' (يذيقهم) (Abadi, 2005, p. 1124; Jauhari, 2009, p.574). The use of the word (يَسُومُونَكُمْ (يَمْن for the meaning of 'feeling' is a form of metaphor. The Ministry translates the word as 'imposing.' It is not a connotative meaning; however, the reader can access the meaning. In addition, the aesthetic aspect of language is neglected.

In Al-baqarah 125 , there is a metaphor in the

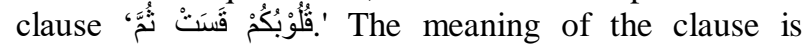
'kemudian hati mereka menjadi keras'/their hearts then become hard. This metaphor is at a phrasal level. The word 'hard' is attached to 'heart,' referring to the situation when people are refusing God as stone cannot accommodate water. In this verse, God portrays a hardhearted man who looks like stone in the river. The original meaning actually refers to a man with full of great things, but God forces to close his heart from his guidance. In the translation made by the Ministry, it was translated by using a literal strategy. It meets the dimension of naturalness and is acceptable in Indonesian grammar.

In Al-baqarah 112, the metaphor could be identified in the word (وَجْهَهُهُ). A similar word was also found in Al-baqarah 144 which in this verse in the form of plural. The word is 'وجو هكم.' In the translation of the Ministry, the word was translated as 'self.' However, Ba'labaki (1995, p. 1224), in the Almawarid dictionary, defines wajh as 'face, side, surface, and aspect.' The use of 'self' is referred to as Pars-pro-toto (a single part for the whole thing). It is a non-literal translation. It is very natural and acceptable in the Indonesian context. The translation adapted the style of the source language. In the verse, the word (الوجه) pertains to the whole body. The word is debatable among scholars. Some scholars define the word as is, while some see the word in allegory. The word (الوجه) was not translated as 'face,' because it would lead to the interpretation of mujassimah (equating God with creatures). The use of 'face' for Allah is nothing more than just to strengthen the influence of God for the believers. Wherever they face, they would always feel that Allah always exists, and they would not be able to turn away from Allah.

In Al-baqarah 125, the metaphor was found in the

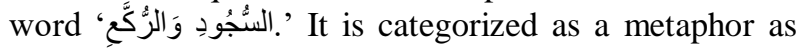
the two words refer to 'prayer' (there are ruku/bowing and sujud/prostration). The words are partly but wholeheartedly referring to 'prayer, it is a metaphor. The metaphors are at a clausal level, namely ' الرَّكَّع ' and 'السُُجُود' has been

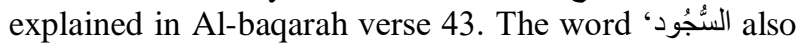
denotes the same reference. The Ministry translated the word using a literal strategy; generating an inaccurate and inappropriate message from the source language.

The metaphors, in a phrasal form, were found in two verses; Al-baqarah 61 and 143. In Al-baqarah 61,

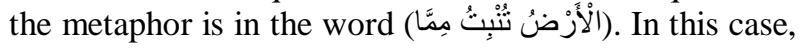
there is an aspect of attributing the verb to the unreal

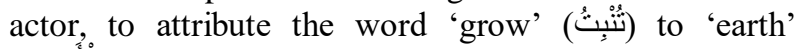

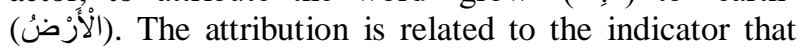
the earth is a place for the plants to grow, but the real creator is God (Asasifah, 2014, p.844). It is a literal translation, which is accurate, natural, and understandable. In Al-baqarah 143, this clause 'يَنْقَبْ وَمَنْنَ عقفيَيْهِ عَلَى ,' conveys a metaphorical language (Az-Zuhaili, 2009 , p. 365). The translation of the verse is 'dan siapa yang membelot/and those who turn on their heels.' This is a non-literal translation. The translator does not translate literally but adopts the general meaning in Arabic. This is acceptable, and will not cause ambiguity. In fact, the literal translation of this clause would lead to difficulty for readers.

The metaphor in clause form was found in Al-

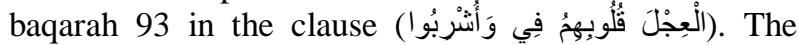
translation of the clause is 'dan diresapkanlah ke dalam hati mereka itu (kecintaan menyembah patung) anak sapi/and their hearts became filled with the love of the calf.' Their worshipping the calf can be attributed to the love of delicious drinks. It is a metaphor as the use of

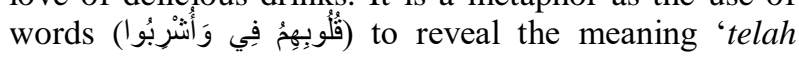
ditancapkan ke dalam hati mereka rasa kecintaan yang mendalam dalam menyembah anak sapil their hearts became filled with the love of the calf. ' In balaghah, it is categorized as the metaphor of istiarah makniyyah (Az-Zuhaili, 2009, p. 248). The translation strategy is non-literal, as the word 'وَأُشْرِبُو ' was translated as 'and filled. This translation is not a lexical translation, like in mu'jam. The metaphor was also identified in Al-baqarah 25 with the clause 'الَّنْهَار تَحَتْهَا مِنْ تَجْرِي.' The translation of it is "surga yang mengalir sungai-sungai di 
dalamnya/gardens beneath which rivers flow." The clause uses a metaphorical language style because what should flow is water (not a river). The translation is literal. Therefore, the metaphorical verses were also translated by using a metaphor to avoid the loss of some key meanings. The use of metaphors in both languages would eliminate some debatable interpretations.

\section{CONCLUSION}

This study concludes that metaphorical verses in the Qur'an take the forms of a word, a phrase, and a clause. When translating metaphorical texts, Quran translators should maintain authenticity or originality of Quranic messages represented in Quranic verses. They have to translate Quranic verses by using tafsiriyyah (a contextual approach to Quranic translation). This suggests that the translation version of Quranic verses does not rest on the literal meaning of the verses, as the translated words are based on the nuances of words which are closely related to the intended meanings. As the case of this translation in this study showed, translators ought to select phrases or texts in a target language which have equivalent meanings to the original words. Therefore, the translated verses may be longer than the original metaphorical verses. Thus, the implication of the study is that when translating metaphorical verses, translators have to focus on discursive meanings. Further textual studies will need to examine the meanings of metaphorical verses using different approaches.

\section{REFERENCES}

Abadi, M. (2005). Alqamusul muhith [muhith dictionary]. Beirut: Arrisalah.

Ainurrafiq, F. (2015). Analisa kesalahan dalam penerjemahan kitab al-balagah al-wadiha karya Ali al-Jarim dan Mustafa Amin [error analysis in the translation of the book Albalaghatul wadhihah by Ali Aljarim and Musthofa Amin]. Jurnal Cendekia, 13(1), 37-48.

Al Farisi, M.Z. (2010). Keterjemahan ungkapan kinayah dalam bahasa Arab ke dalam bahasa Indonesia [translation of kinayah phrases in Arabic into Indonesian]. Jurnal Bahasa \& Sastra, 10(2), 188200.

Al Farisi, M.Z. (2013). Aspek relevansi dalam terjemahan tindak-tutur kinayah Al-Qur'an [the dimension of relevance in the translation of the Qur'anic acts]. KARSA: Jurnal Sosial \& Budaya Keislaman, 2(21), 156-169. doi: 10.19105/karsa.v21i2.515

Al Farisi, M.Z. (2015). Keberterimaan terjemah ayatayat imperatif Al-Quran [the acceptability of translation of the imperative verses of the Quran]. (Unpublished doctoral thesis). Universitas Pendidikan Indonesia, Bandung, Indonesia. Al-Thabari, M. (2000). Jami'ul bayan fi ta'wilil Quran [a complete explanation of the interpretation of the Quran]. Beirut: Muassasah Arrisalah.

Asasifah, A. (2014). Almajaz fin nasyah wath thathowwur [metaphor and its development in Arabic]. Jurnal Dirosatul Ulumil Insaniyyah wal Ijtimaiyyah, 41(2), 844-854.

Asfahani, R. (2009). Mujam mufrodat alfadzil Quran [the encyclopedia of the Quran vocabulary]. Beirut: Darusy Syamiah.

Atiq, A. (1985). Ilmul bayan [rhetoric]. Beirut: Darun Nahdhoh Alarabiyyah.

Az-Zuhalili, W. (2009). Attafsirul munir [Qur'anic commentary that illuminates]. Jilid I. Damaskus: Darul Fikri.

Ba'labaki, R. (1995). Al-Maurid [Resources]. Beirut: Darul Ilmi lil Malayin.

Belloc. H. (1931). On translation. Oxford: Oxford University Press.

Dobrzynska, T. (1995). Translating metaphor: Problems of meaning. Journal of Pragmatics, 24(6), 595604. doi: 10.1016/0378-2166(95)00022-K

Eliman, H. (2016). Translation of metaphor in the holy Quran. (Unpublished master's thesis). American University of Sharjah College, Sharjah, UEA.

Hasyimi, S. (1994). Jawāhirul balāghah [pearl of language beauty]. Beirut: Darul Fikri.

Ibn Faris, A. (1979). Mujam maqoyisul lughah [dictionary of language standards]. Beirut: Darul Fikr.

Ibnu Jinni. (1343). Alkhashaish [language properties]. Darul Kutubil Arabiyyah.

Ibnul Atsir, D. (1939). Almutsulus sair fi adabil katib wassair [the proverbial proverb in the literature of writer and traveler]. Kairo: Darun Nahdhoh.

Jauhari, A. (2009). Tajullughah wa shihahul arabiyyah [dictionary of the language crown and corrected the Arabic]. Kairo: Darul Hadits.

Jurzani, A. (1988). Asrorul balaghah [pearl of Arabic beauty]. Beirut: Darul Fikr.

Kashgary, A. D. (2011). The paradox of translating the untranslatable: Equivalence vs. non-equivalence in translating from Arabic into English. Journal of King Saud University - Languages and Translation, 23, 47-57. doi: 10.1016/j.jksult.2010.03.001

Larson, M. L. (1998). Meaning-based translation: A Guide to cross-language equivalence (Second edition). Boston: University Press of America.

Lubis, T. (2011). Alhaqiqah wal majaz indal ushuliyyin wal lughawiyyin [denotative and connotative meaning in the view of ushul fiqh experts and linguists]. Jurnal Lingua, 3(2). doi: 10.18860/ling.v3i2.581

Mahadi, S. A. S. (2015). Translators as Cultural Mediators in Transmitting Cultural Differences. Procedia - Social and Behavioral Sciences, 208, 167-174. doi: 10.1016/j.sbspro.2015.11.193

Muzakki, A. (2009). Gaya bahasa metapor dalam Alquran [the metaphors in the Koran]. Jurnal Lingua, 4(2). doi: 10.18860/ling.v4i2.601 
Nababan, M., Ardiana, N., \& Sumardiono. (2012). Pengembangan model penilaian kualitas terjemahan [development of a translation quality assessment model]. Jurnal Kajian Linguistik dan Sastra, 24(1), 39-57. doi: 10.23917/kls.v24i1.101

Nawawi, M. (2017). Eksistensi majaz dalam Alquran sebagai khazanah keilmuan Islam [the existence of metaphors in the Quran as a treasure of Islamic scholarship]. Jurnal Al-A'raf, XIV(2), 239-252. doi: 10.22515.ajpif.v14i2.481

Newmark, P. (1998). A Text book of translation. London: Prentice-Hall.

Nida, E. A. (1943). Towards a Science of Translation, with Special Reference to Principles and Procedures Involved in Bible Translating. Leiden: Brill.

Nida, E. A. \& Taber, C. R. (1969). The Theory and practice of translation. Leiden: Brill.

Nurbayan, Y. (2009). Implikasi hermeneutik dan pedagogis perbedaan pemahaman ayat-ayat kinayah dalam Alquran [the hermeneutic and pedagogical implications of the difference in understanding kinayah verses in the Quran]. Jurnal Lingua, 4(2). doi: 10.18860/ling.v4i2.595

Rahimy, R. (2004). Alpha, beta and gamma features in translation: Towards the objectivity of testing translation. Translation Studies, 2 (5), 53-62.

Sanqiti. (2009). Man'u jawazil majaz fil munazzali littaabbudi wal i'jaz [preventing the permissibility of metaphor in the Quran to worship and miracles]. Jeddah: Majmaul Fiqhil Islami.
Seong, G. S. (2011). Penerjemahan kata kerja bahasa cina-bahasa Melayu: Satu analisis ketepatan makna padanan [translation of the verb ChineseMalay: One analysis of the accuracy of the equivalent meaning]. Gema Online Journal of Language Studies, 11(1), 35-56.

Shanmugam, K. (2010). Pantun translation into english in women's writings in twentieth century British Malaya. Journal of Modern Languages, 20(1), 8093.

Sukamta. (2009). Majaz dan pluralitas makna dalam Alquran [metaphor and plurality of meanings in the Qur'an]. Yogyakarta: Adab Press UIN Sunan Kalijaga.

Syamsuddin, S. (2009). Hermeneutika dan pengembangan ulumul Quran [hermeneutics and the development of ulumul Quran]. Yogyajarta, Indonesia: Wanesia.

Thriveni, C. (2002). Cultural elements in translation: The Indian perspective. Retrieved from http://www.translationdirectory.com/article24.htm

Tytler, A. (1797). Essay on The Principles of Translation, Edinburgh: Cadell \& Davies.

Zamakhsyari. (2009). Tafsirul kasysyaf an haqoiqittanzil wa uyunil aqowil fi wujuhittakwil [an opening interpretation of the essence of the meaning of the Quran]. Beirut: Darul Marifah.

Zarkasyi, M. (1957). Alburhan fi ulumil Quran [evidence on the knowledge of Quran]. Kairo: Darut Turots. 